\title{
Naoxintong/PPAR $\alpha$ Signaling Inhibits H9c2 Cell Apoptosis and Autophagy in Response to Oxidative Stress
}

\author{
Huimin Xu, ${ }^{1,2}$ Jianhua Jin, ${ }^{1}$ Lu Chen, ${ }^{3,4}$ Chunxiao Li, ${ }^{3,4}$ Qinggang Xu, ${ }^{2}$ Juanjuan Shi, ${ }^{2}$ \\ Buchang Zhao, ${ }^{5}$ Yongzhong Hou, ${ }^{1,2}$ and Hong Wang ${ }^{3,4,6}$ \\ ${ }^{1}$ Department of Oncology, Affiliated Wujin People's Hospital, Jiangsu University, Changzhou 212017, China \\ ${ }^{2}$ Institute of Life Sciences, Jiangsu University, Zhenjiang, Jiangsu 212013, China \\ ${ }^{3}$ Tianjin State Key Laboratory of Modern Chinese Medicine, Tianjin University of Traditional Chinese Medicine, 312 Anshanxi Road, \\ Nankai District, Tianjin 300193, China \\ ${ }^{4}$ Key Laboratory of Pharmacology of Traditional Chinese Medical Formulae, Tianjin University of Traditional Chinese Medicine, \\ Ministry of Education, Tianjin 300193, China \\ ${ }^{5}$ Xi'an Buchang Cardio-Cerebrovascular Disease Hospital, Xi'an 710003, China \\ ${ }^{6}$ Tianjin Key Laboratory of Traditional Chinese Medicine Pharmacology, Tianjin University of Traditional Chinese Medicine, \\ 88 Yuquan Road, Nankai District, Tianjin 300193, China
}

Correspondence should be addressed to Yongzhong Hou; houyz@mail.ujs.edu.cn and Hong Wang; wanghongsys@126.com

Received 31 March 2016; Accepted 21 June 2016

Academic Editor: Yoshiji Ohta

Copyright (C) 2016 Huimin Xu et al. This is an open access article distributed under the Creative Commons Attribution License, which permits unrestricted use, distribution, and reproduction in any medium, provided the original work is properly cited.

Naoxintong (NXT) is an empirical formula based on the principle of traditional Chinese medicine, which has been approved by China Food and Drug Administration (CFDA) and is widely used for treatment of patients with cerebrovascular and cardiovascular diseases in China. The aim of this study is to investigate the protective mechanism of NXT on H9c2 cells (cardiogenic cell line) in response to $\mathrm{H}_{2} \mathrm{O}_{2}$. MTT, Western blot, and flow cytometry (FCM) methods were used to identify the protective effect of NXT extract on $\mathrm{H}_{2} \mathrm{O}_{2}$-induced $\mathrm{H} 9 \mathrm{c} 2$ cells. Here we found that NXT extract significantly increased $\mathrm{H} 9 \mathrm{c} 2$ cell viability and reduced $\mathrm{H}_{2} \mathrm{O}_{2}$-induced cell apoptosis and autophagy. More importantly, NXT inhibited $\mathrm{H}_{2} \mathrm{O}_{2}$-induced $\mathrm{H} 9 \mathrm{c} 2$ cell apoptosis and autophagy by increasing PPAR $\alpha$ protein levels. In contrast, silenced PPAR $\alpha$ terminated NXT protective effect on $\mathrm{H}_{2} \mathrm{O}_{2}$-induced $\mathrm{H} 9 \mathrm{c} 2$ cells. These findings suggest that NXT/PPAR $\alpha$ signaling suppressed $\mathrm{H}_{2} \mathrm{O}_{2}$-induced $\mathrm{H} 9 \mathrm{c} 2$ cell apoptosis and autophagy.

\section{Introduction}

Naoxintong (NXT) is an empirical formula based on the principle of traditional Chinese medicine, which has been approved by China Food and Drug Administration (CFDA, Z20025001) and widely used for treatment of patients with cerebrovascular and cardiovascular diseases in China. NXT contains sixteen kinds of traditional Chinese medicines including Astragalus membranaceus (Fish.) Bge. (Huangqi), Radix Paeoniae (Chishao), Salviae miltiorrhizae radix et rhizoma (Danshen), Radix Angelicae Sinensis (Danggui), Radix Paeoniae Rubra (Chishao), Rhizoma Ligustici Chuanxiong (Chuanxiong), Semen Persicae (Taoren), Achyranthes bidentata (Niuxi), Spatholobus stem (Jixueteng), Mulberry Twig (Sangzhi), Cassia Twig (Guizhi), Boswellia carteri (Ruxiang), and Commiphora myrrha Eng1 (Moyao) and animal medicines including hirudo nipponica Whitman (Shuizhi), Scorpio (Quanxie), and Pheretima (Dilong). NXT alleviates atherosclerosis involved in inhibition of iNOS expression and dendritic cell maturation $[1,2]$. Clinical observation shows that NXT can increase antiplatelet effect and decrease subsequent major adverse cardiovascular events (MACE) in patients with cytochrome $\mathrm{P} 4502 \mathrm{Cl}^{*} 2$ polymorphism undergoing percutaneous coronary intervention (PCI) [3]. Moreover, NXT reduces the development of diabetic retinopathy [4] and cardiomyocyte damage in response to 
reactive oxygen species (ROS) [5]; however, the mechanism of NXT on the cardiomyocyte apoptosis and autophagy in response to oxidative stress is still unclear.

Oxidative stress plays an important role in the pathogenesis of cardiovascular diseases. ROS is a main oxidative stress in cardiovascular damage. ROS is a byproduct of the normal metabolism of oxygen and has important roles in the cell signaling and homeostasis. But too much ROS production leads to oxidative stress [6]. The myocardial ischemia-reperfusion pathophysiologically produces ROS upon the restoration of blood flow [7]. ROS can be induced by hyperglycemia or $\mathrm{H}_{2} \mathrm{O}_{2}$ in vitro. At present, extracellular $\mathrm{H}_{2} \mathrm{O}_{2}$-induced $\mathrm{H} 9 \mathrm{c} 2$ cell injury model is well documented [8]. Our previous study shows that the extract of Angelica sinensis and Ligusticum chuanxiong has protective effect against $\mathrm{H}_{2} \mathrm{O}_{2}$-induced endothelial cell damage [9] and inhibits rat vascular smooth muscle cell proliferation [10]. PPAR $\alpha$ plays a protective role in cardiomyocyte damage [11], while the mechanism of NXT water extract protecting cardiomyocyte from $\mathrm{H}_{2} \mathrm{O}_{2}$ induced damage is not well known. Here we found that NXT activated PPAR $\alpha$ signaling decreased $\mathrm{H}_{2} \mathrm{O}_{2}$-induced $\mathrm{H} 9 \mathrm{c} 2$ cell apoptosis and autophagy.

\section{Materials and Methods}

2.1. NXT Water Extract. NXT was kindly provided by Xianyang Buchang Pharmaceutical Co. Ltd. (Shanxi, China). The NXT water extract was isolated from $5 \mathrm{~g}$ NXT powder incubating in $15 \mathrm{~mL} \mathrm{H}_{2} \mathrm{O} 60^{\circ} \mathrm{C}$ for $6 \mathrm{hs}$, and then the solution was evaporated to $1 \mathrm{~mL}$ and filtered. The composition of NXT water extract was identified by UHPLC-Q-TOF Tandem Mass Spectrometry.

2.2. Cell Culture. The rat embryonic-heart derived $\mathrm{H} 9 \mathrm{c} 2$ cell line (ATCC, CRL-1446). Cells were cultured at $37^{\circ} \mathrm{C}$ and $5 \%$ $\mathrm{CO}_{2}$ in $25 \mathrm{~mL}$ cell culture flask containing Dulbecco's Modified Eagle Medium (DMEM) (Gibco) supplemented with 10\% (v/v) Fetal Bovine Serum (FBS) (Gibco), $100 \mathrm{U} / \mathrm{mL}$ penicillin, and $100 \mu \mathrm{g} / \mathrm{mL}$ streptomycin sulfate. Cells were maintained in exponential phase of growth and were subcultured when they reached about $80 \%$ confluence at a split ratio of $1: 3$.

2.3. Cell Viability Assay. MTT assay was used to screen the cytotoxic or protective activity of the water extract compound from NXT. The cell viability was determined with MTT Cell Proliferation and Cytotoxicity Assay Kit (Sangon) according to the manufacturer's instructions. Cells $\left(1 \times 10^{3}\right.$ cells/well $)$ were seeded in 96 -well plates. After the corresponding treatment, cells were washed twice with PBS and then incubated with the MTT solution for $1.5 \mathrm{~h}$ at $37^{\circ} \mathrm{C}$. Cells were then dissolved in $200 \mu \mathrm{L}$ DMSO in 96-well plates. The absorbance of the reaction solution at $570 \mathrm{~nm}$ was measured with an ELISA-plate reader, Multidetection Microplate Reader Synergy H4 (BioTek).

2.4. Western Blot. Cells were seeded in 6-well plates and cultured as mentioned above. Cells were lysed in lysis buffer containing protease inhibitors. The lysate was sonicated $(10 \mathrm{~s})$ and then centrifuged at $13,000 \times \mathrm{g}$ at $4^{\circ} \mathrm{C}$ for $10 \mathrm{~min}$.
Protein concentration in the supernatant was determined by the Pierce BCA Protein Assay Kit (Thermo). Samples were diluted $(1: 4)$ in protein loading buffer $(67 \mathrm{mM}$ Tris$\mathrm{HCl}, \mathrm{pH} 6.8,30 \%$ glycerol, $2 \%$ SDS, and $0.01 \%$ bromophenol blue) and boiled for $5 \mathrm{~min}$. The proteins were separated by SDS-PAGE using 10\% acrylamide gels and transferred to a nitrocellulose membrane (PALL). After being blocked with $5 \%(\mathrm{w} / \mathrm{v})$ nonfat dry milk dissolved in TBST buffer $(10 \mathrm{mM}$ Tris- $\mathrm{HCl} \mathrm{pH} \mathrm{7.5,} 150 \mathrm{mM} \mathrm{NaCl}$, and $0.1 \%$ Tween 20), the membranes were incubated with primary antibodies, anticascas3/9, anti-PARP-1, Bcl-2, Bax, Bad, and beta-actin (Santa Cruz Biotechnology) and LC3b antibody (Novus Biologicals). The membranes were washed three times with TBST buffer at room temperature and then incubated with HRP-conjugated secondary antibody for $1 \sim 2 \mathrm{~h}$ at room temperature. The secondary antibody was removed by washing three times with TBST buffer. The immunoreactive bands were visualized with ECL reagent.

2.5. Plasmids and Transfection. PPAR $\alpha$ shRNA plasmids (GV248 vector) were purchased from GeneCHEM (China). Plasmids were transfected by turboFect transfection reagent according to the manufacturer's instructions (Thermo Scientific).

2.6. Flow Cytometry (FCM) Assay. Cells were harvested by trypsinization and centrifuged at $400 \times \mathrm{g}$ at $4^{\circ} \mathrm{C}$ for $10 \mathrm{~min}$. For each sample, $10^{6}$ cells were collected. The cells were treated with Annexin V-FITC Apoptosis Detection Kit according to the manufacturer's instructions (BD Biosciences). The cells flow through the FCM at about 100-1000 cells per second.

2.7. Statistical Analysis. Data are expressed as the mean \pm SEM. Statistical comparison was carried out with Student's $t$ test or one-way analysis of variance (ANOVA).

\section{Results}

3.1. Determination of Composition in NXT Water Extract by UHPLC-Q-TOF. The UHPLC-Q-TOF results show that the main composition of NXT water extract is paeoniflorin $(80.4 \%)$, salvianolic acid B (10.1\%), trihydroxybenzoic acid (4.6\%), chlorogenic acid (1.8\%), and ferulic acid (1.5\%). The relative concentration of the main compositions was calculated (Table 1).

3.2. NXT Increases Cell Viability in Response to $\mathrm{H}_{2} \mathrm{O}_{2}$. $\mathrm{H} 9 \mathrm{c} 2$ cells were treated with $\mathrm{H}_{2} \mathrm{O}_{2}$. The results show that $\mathrm{H}_{2} \mathrm{O}_{2}$ dose dependently reduced cell viability (Figure 1(a)). Further analysis shows that the NXT extract had no cytotoxicity effect on H9c2 cells (Figure 1(b)). To assay the protective effect of NXT on H9c2 cells, cells were pretreated with different dose $(0.1 \sim 1.0 \mu \mathrm{g} / \mathrm{mL})$ of NXT for $12 \mathrm{~h}$. After that cells were induced with $\mathrm{H}_{2} \mathrm{O}_{2}$ for $6 \mathrm{~h}$. The results show that NXT significantly increased cell survival in response to $\mathrm{H}_{2} \mathrm{O}_{2}$ (Figure 1(c)).

3.3. NXT Increases Antiapoptotic Protein Expression in Response to $\mathrm{H}_{2} \mathrm{O}_{2}$. The antiapoptotic MCL-1 protein prevents 
TABLE 1: Diverse composition in NXT water extract identified by UHPLC-Q-TOF.

\begin{tabular}{lccccc}
\hline Number & Peak number & Identification & Formula & MS & Relative concentration (\%) \\
\hline 1 & 35 & Paeoniflorin & $\mathrm{C}_{23} \mathrm{H}_{28} \mathrm{O}_{11}$ & 480.1632 & 80.42 \\
2 & 55 & Salvianolic acid B & $\mathrm{C}_{36} \mathrm{H}_{30} \mathrm{O}_{16}$ & 718.1534 & 10.13 \\
3 & 11 & Gallic acid & $\mathrm{C}_{7} \mathrm{H}_{6} \mathrm{O}_{5}$ & 170.0215 & 4.59 \\
4 & 22 & Chlorogenic acid & $\mathrm{C}_{16} \mathrm{H}_{18} \mathrm{O}_{9}$ & 354.0951 & 1.79 \\
5 & 39 & $\mathrm{C}_{10} \mathrm{H}_{10} \mathrm{O}_{4}$ & 194.0579 & 1.53 \\
6 & 25 & Ferulic Acid & $\mathrm{C}_{27} \mathrm{H}_{32} \mathrm{O}_{16}$ & 612.1690 & 0.80 \\
7 & 49 & Hydroxysafflor yellow A & $\mathrm{C}_{18} \mathrm{H}_{16} \mathrm{O}_{8}$ & 360.0845 & 0.22 \\
8 & 16 & Rosmarinic acid & $\mathrm{C}_{6} \mathrm{H}_{6} \mathrm{O}_{3}$ & 126.0317 & 0.17 \\
9 & 47 & 5-Hydroxymethylfurfural & $\mathrm{C}_{25} \mathrm{H}_{24} \mathrm{O}_{12}$ & 516.1268 & 0.14 \\
10 & 46 & 1,5-Di-O-caffeoylquinic acids & $\mathrm{C}_{25} \mathrm{H}_{24} \mathrm{O}_{12}$ & 516.1268 & 0.11 \\
11 & 48 & 3,5-Di-O-caffeoylquinic acids & $\mathrm{C}_{27} \mathrm{H}_{30} \mathrm{O}_{15}$ & 594.1585 & 0.07 \\
\hline
\end{tabular}

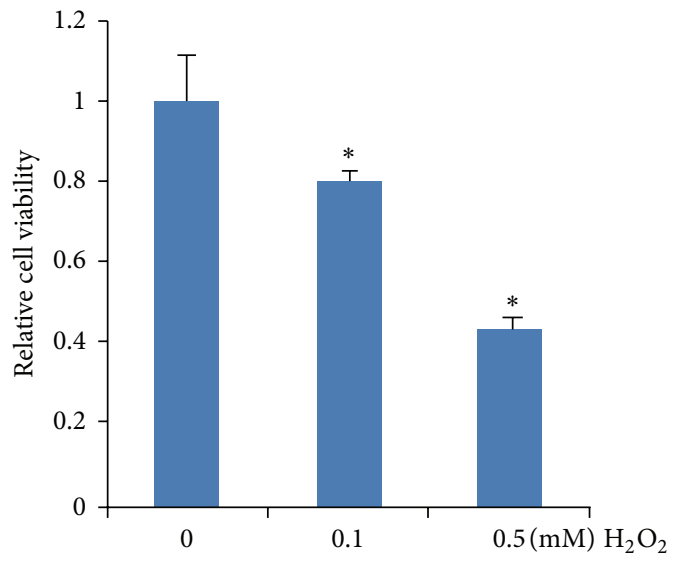

(a)

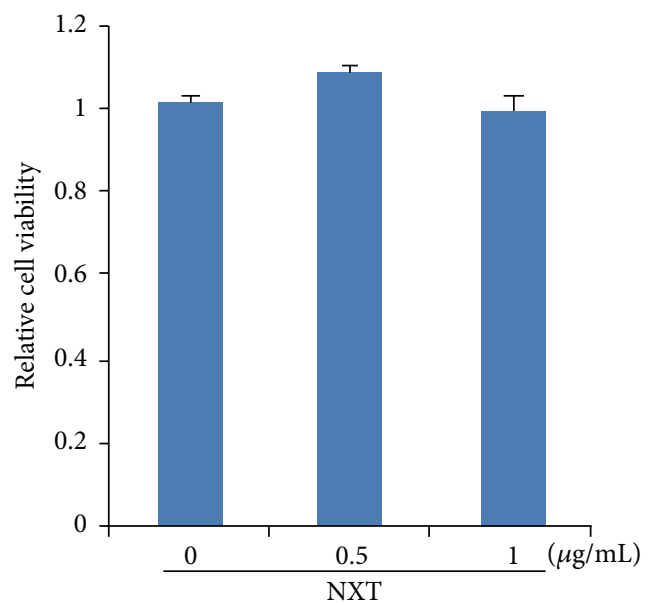

(b)

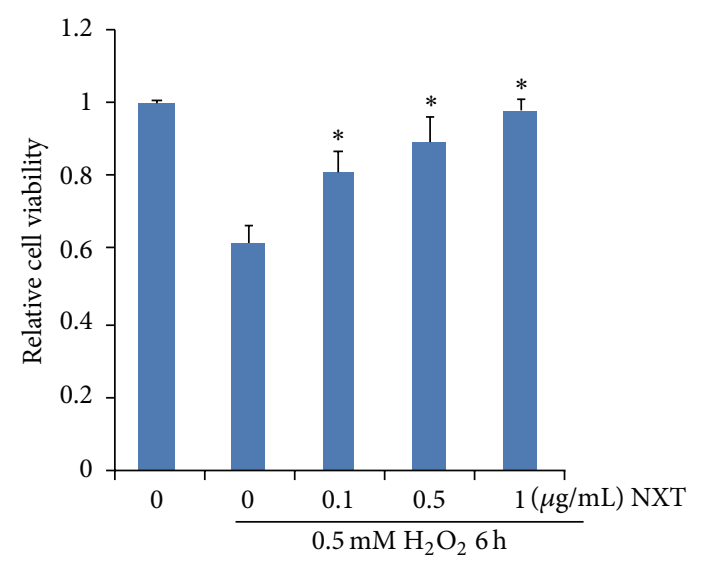

(c)

FIgURE 1: NXT extract increases cell viability. (a) $\mathrm{H} 9 \mathrm{c} 2$ cells were treated with $\mathrm{H}_{2} \mathrm{O}_{2}$ as indicated for 6 h. Cell viability was assayed by MTT. Results are expressed as means $\pm \operatorname{SEM}(n=5) .{ }^{*} \mathrm{P}<0.05$ versus no $\mathrm{H}_{2} \mathrm{O}_{2}$ treatment. (b) H9c2 cells were treated with NXT extract as indicated for $12 \mathrm{~h}$. Cell viability was assayed by MTT. (c) H9c2 cells were pretreated with or without NXT extract for $12 \mathrm{~h}$, and then cells were treated with $0.5 \mathrm{mM} \mathrm{H}_{2} \mathrm{O}_{2}$ for $6 \mathrm{~h}$ as indicated. Cell viability was assayed by MTT. Results are expressed as means \pm SEM $(n=5)$. ${ }^{*} P<0.05$ versus no NXT treatment. 


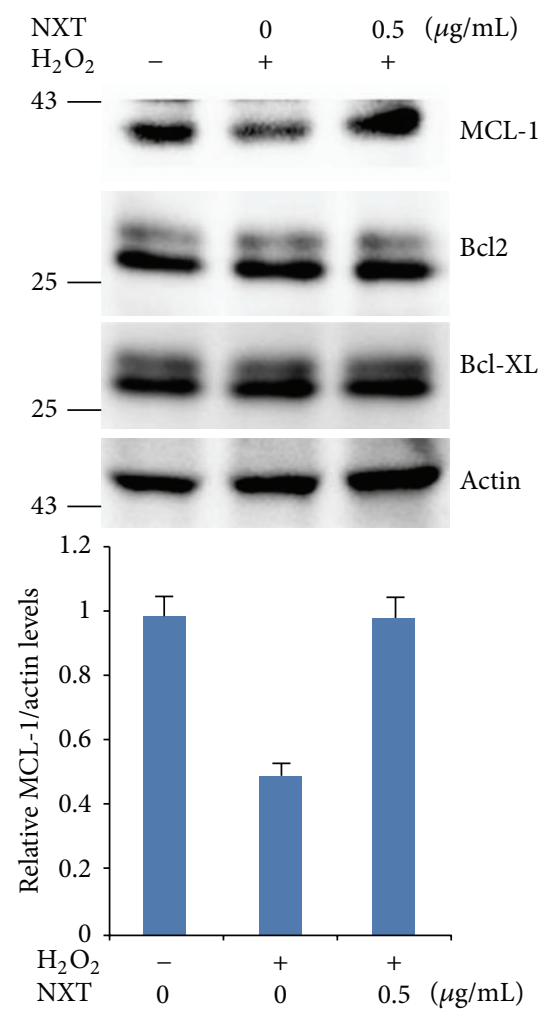

(a)
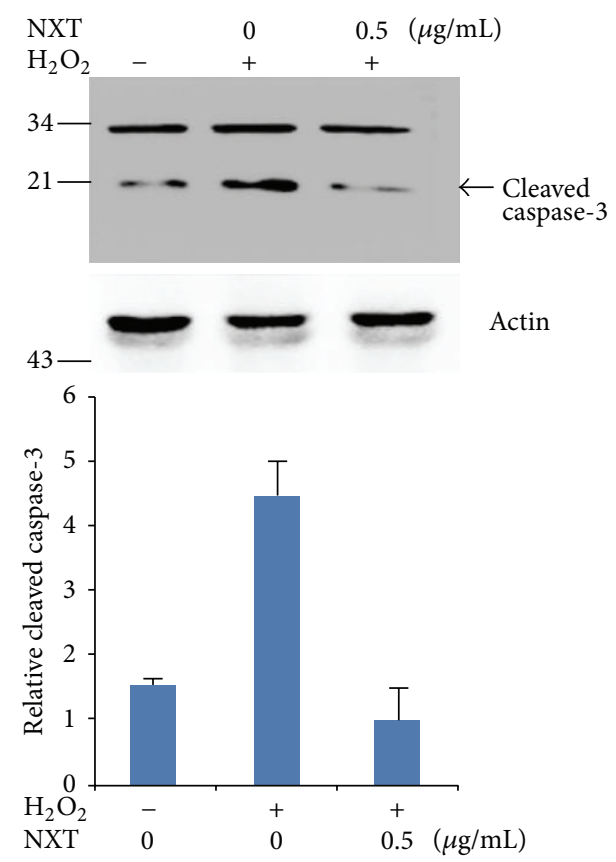

(c)

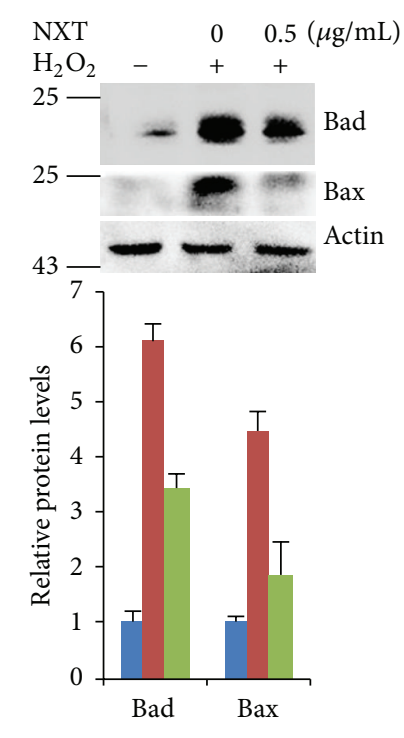

0

- $\mathrm{H}_{2} \mathrm{O}_{2}$

- $\mathrm{H}_{2} \mathrm{O}_{2}+\mathrm{NXT}$

(b)

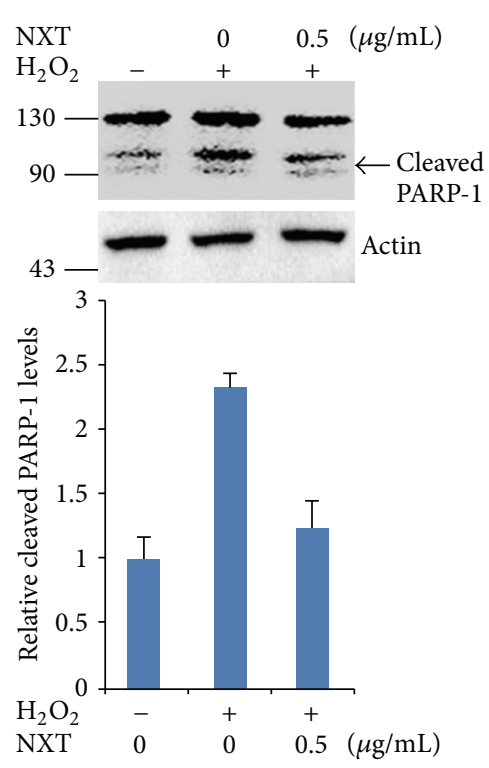

(d)

FIGURE 2: NXT increases antiapoptotic protein levels. (a) H9c2 cells were pretreated with or without $0.5 \mu \mathrm{g} / \mathrm{mL}$ NXT for $12 \mathrm{~h}$, and then the cells were treated with $200 \mu \mathrm{M} \mathrm{H}_{2} \mathrm{O}_{2}$ for $6 \mathrm{~h}$. Cell lysates were subjected to Western blot. (b) $\mathrm{H} 9 \mathrm{c} 2$ cells were pretreated with or without $0.5 \mu \mathrm{g} / \mathrm{mL}$ NXT for $12 \mathrm{~h}$, and then the cells were treated with $200 \mu \mathrm{M} \mathrm{H}_{2} \mathrm{O}_{2}$ for $6 \mathrm{~h}$. Cell lysates were subjected to Western blot as indicated. (c) $\mathrm{H} 9 \mathrm{c} 2$ cells were pretreated with or without $0.5 \mu \mathrm{g} / \mathrm{mL}$ NXT for $12 \mathrm{~h}$, and then the cells were treated with $200 \mu \mathrm{M} \mathrm{H} \mathrm{H}_{2} \mathrm{O}_{2}$ for $6 \mathrm{~h}$. Cell lysates were subjected to Western blot as indicated. (d) H9c2 cells were pretreated with or without $0.5 \mu \mathrm{g} / \mathrm{mL}$ NXT for $12 \mathrm{~h}$, and then the cells were treated with $200 \mu \mathrm{M} \mathrm{H}_{2} \mathrm{O}_{2}$ for $6 \mathrm{~h}$. Cell lysates were subjected to Western blot. Data are triplicates from three independent experiments. 

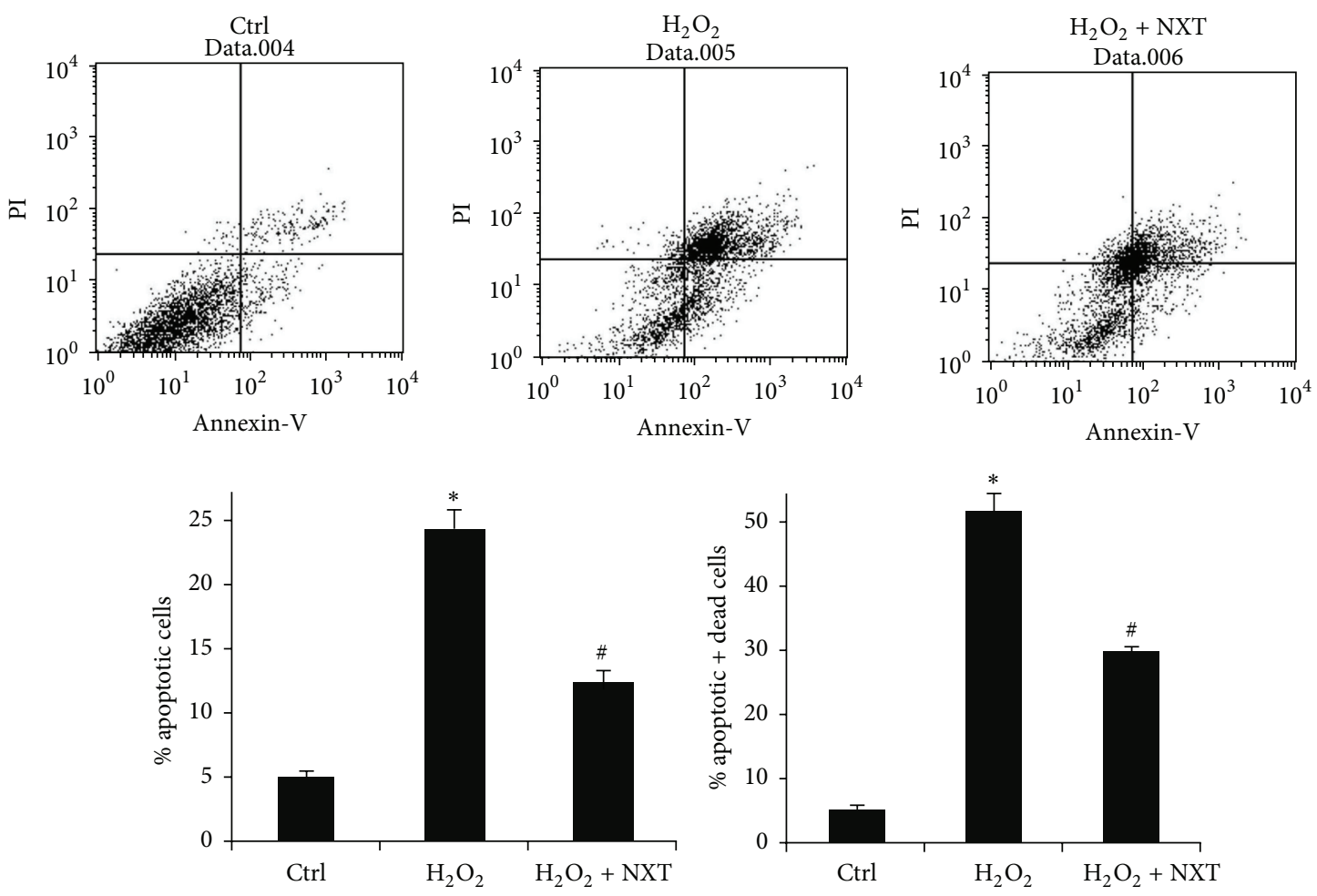

FIGURE 3: NXT extract inhibits $\mathrm{H}_{2} \mathrm{O}_{2}$-induced cell apoptosis. $\mathrm{H} 9 \mathrm{c} 2$ cells were pretreated with or without $0.5 \mu \mathrm{g} / \mathrm{mL} \mathrm{NXT}$ for $12 \mathrm{~h}$, and then the cells were treated with $200 \mu \mathrm{M} \mathrm{H}_{2} \mathrm{O}_{2}$ for $6 \mathrm{~h}$. Cell apoptosis was assayed by FCM. Apoptotic cells or apoptotic and death cells were quantified. ${ }^{*} P<0.05$ Ctrl versus $\mathrm{H}_{2} \mathrm{O}_{2}$ only treatment; ${ }^{\#} \mathrm{P}<0.05 \mathrm{H}_{2} \mathrm{O}_{2}$ versus NXT treatment. Data are triplicates from three independent experiments.

the release of mitochondrial contents against caspase- 3 activation $[12,13]$. We next detected the effect of NXT on the cell apoptotic signaling. The results show that NXT extract significantly increased antiapoptotic MCL-1 protein levels (Figure 2(a)). In contrast, NXT decreased $\mathrm{Bad}$ and $\mathrm{Bax}$ proapoptotic protein levels (Figure 2(b)) $\mathrm{H}_{2} \mathrm{O}_{2}$ induces cell apoptosis through activate caspase-3 $[12,13]$. Our results show that NXT extract reversed this apoptotic signaling by inhibiting caspase-3 activation (Figure 2(c)); subsequently, cleaved PARP-1 was decreased in H9c2 cells treated with NXT extract (Figure 2(d)). These findings suggest that NXT inhibited the $\mathrm{H} 9 \mathrm{c} 2$ cell apoptosis through inhibiting activation of caspase-3/PARP-1 signaling pathway.

3.4. NXT Decreases Cell Apoptosis. To detect NXT protective effect on $\mathrm{H} 9 \mathrm{c} 2$ cells in response to $\mathrm{H}_{2} \mathrm{O}_{2}$, flow cytometry analysis was performed to detect the effect of NXT on $\mathrm{H}_{2} \mathrm{O}_{2}$-induced $\mathrm{H} 9 \mathrm{c} 2$ cell apoptosis. The results show that $\mathrm{H}_{2} \mathrm{O}_{2}$ significantly induced cell apoptosis, but NXT reversed this event (Figure 3), suggesting that NXT extract inhibited $\mathrm{H}_{2} \mathrm{O}_{2}$-induced $\mathrm{H} 9 \mathrm{c} 2$ cell apoptosis associated with increased antiapoptotic protein levels.

3.5. NXT Inhibits Cell Apoptosis by Increasing PPAR $\alpha$ Expression. Our data have demonstrated that NXT significantly decreased $\mathrm{H} 9 \mathrm{c} 2$ cell apoptosis in response to $\mathrm{H}_{2} \mathrm{O}_{2}$, which was involved in increasing antiapoptotic protein expression.
As nuclear receptor, PPAR is a critical regulator of inflammation, adipocyte differentiation, and glucose homeostasis $[3,14-17]$. Other reports show that PPAR $\alpha$ protects against cardiomyocyte damage $[11,18]$. Here we found that $\mathrm{H}_{2} \mathrm{O}_{2}$ significantly reduced PPAR $\alpha$ protein levels (Figure 4(a)), but NXT increased PPAR $\alpha$ protein expression levels (Figure 4(b)). More importantly, cells pretreated with NXT did not reduce PPAR $\alpha$ protein levels in response to $\mathrm{H}_{2} \mathrm{O}_{2}$ (Figure 4(c)). Further analysis shows that PPAR $\alpha$ silenced $\mathrm{H} 9 \mathrm{c} 2$ cells increased proapoptotic protein levels (Bax and $\mathrm{Bad}$ ) and decreased antiapoptotic protein MCL-1 protein levels (Figure 5(a)). Consistent with this, PPAR $\alpha$ silenced $\mathrm{H} 9 \mathrm{c} 2$ cells led to increased activation of caspase- 3 in response to $\mathrm{H}_{2} \mathrm{O}_{2}$ (Figure 5(b)). As expected, PPAR $\alpha$ silence in $\mathrm{H} 9 \mathrm{c} 2$ cells did not increase cell survival in response to $\mathrm{H}_{2} \mathrm{O}_{2}$ (Figure 5(c)). These findings show that NXT activated PPAR $\alpha$ singling leading to inhibition of $\mathrm{H}_{2} \mathrm{O}_{2}$-induced $\mathrm{H} 9 \mathrm{c} 2$ cell damage.

3.6. NXT Reduces Cell Autophagy in Response to $\mathrm{H}_{2} \mathrm{O}_{2}$. Mammalian cell death has three types: apoptosis, necrosis, and autophagy [12]. We further detected whether $\mathrm{H}_{2} \mathrm{O}_{2}$ would induce cardiomyocyte autophagy. As expected, $\mathrm{H}_{2} \mathrm{O}_{2}$ significantly increased processing of LC3-I to LC3-II conversion (Figure 6(a)), suggesting that $\mathrm{H}_{2} \mathrm{O}_{2}$ induced $\mathrm{H} 9 \mathrm{c} 2$ cell autophagy. Further analysis shows that $\mathrm{H}_{2} \mathrm{O}_{2}$-induced cell autophagy was reduced by NXT treatment (Figure 6(b)), suggesting that NXT decreased $\mathrm{H}_{2} \mathrm{O}_{2}$-induced $\mathrm{H} 9 \mathrm{c} 2$ cell 

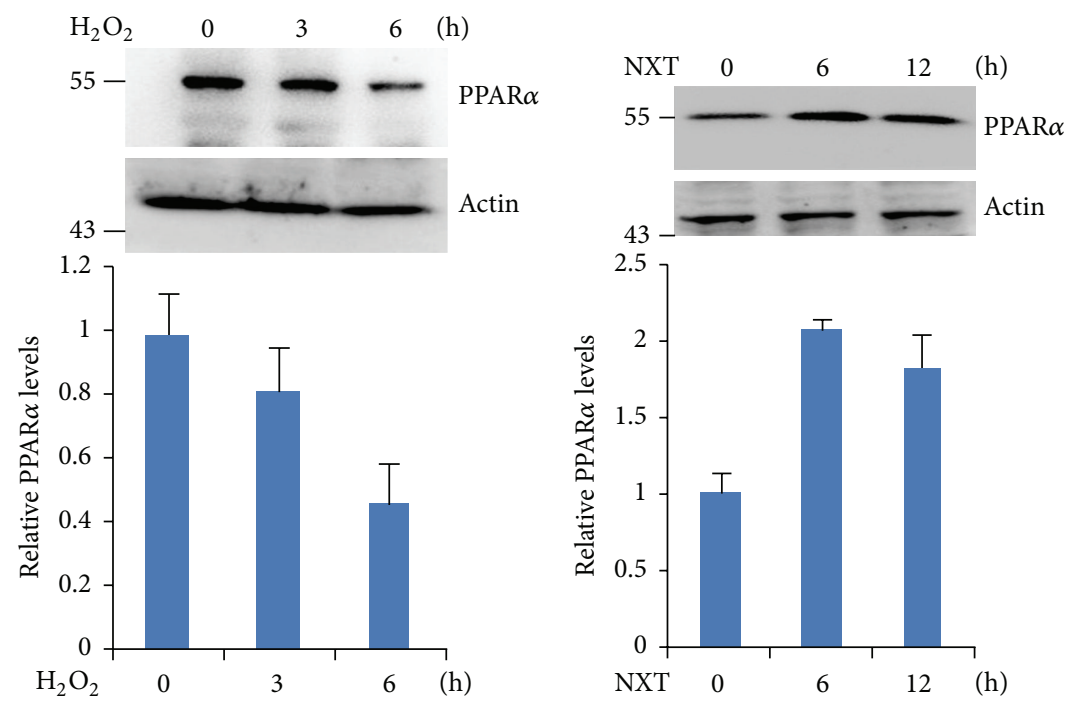

(a)

(b)

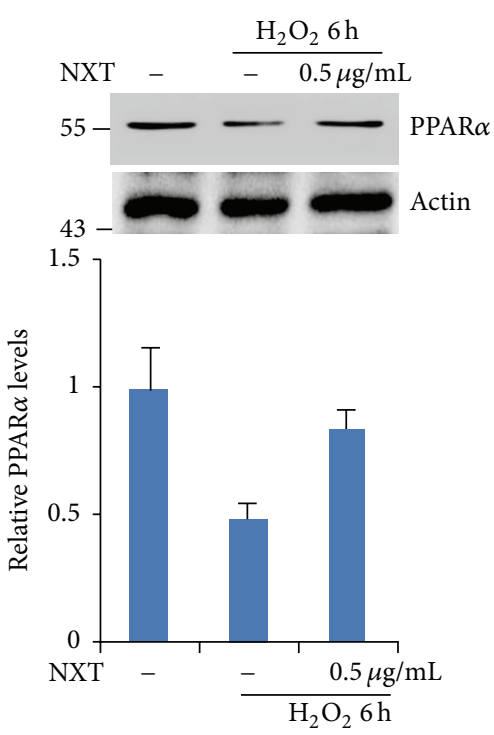

(c)

FIgURE 4: NXT extract increases PPAR $\alpha$ expression. (a) H9c2 cells were treated with $200 \mu \mathrm{M} \mathrm{H}_{2} \mathrm{O}_{2}$ as indicated time. Cell lysates were subjected to Western blot. (b) $\mathrm{H} 9 \mathrm{c} 2$ cells were treated with $0.5 \mu \mathrm{g} / \mathrm{mL}$ NXT as indicated time. Cell lysates were subjected to Western blot. (c) $\mathrm{H} 9 \mathrm{c} 2$ cells were treated with or without $0.5 \mu \mathrm{g} / \mathrm{mL}$ NXT for $12 \mathrm{~h}$. After that, cells were treated with $200 \mu \mathrm{M} \mathrm{H}_{2} \mathrm{O}_{2}$ for $6 \mathrm{~h}$. Cell lysates were subjected to Western blot. Data are triplicates from three independent experiments.

autophagy. As PPAR $\alpha$ inhibited $\mathrm{H}_{2} \mathrm{O}_{2}$-induced cell apoptosis, further analysis shows that PPAR $\alpha$ silence led to increased H9c2 cell autophagy (Figure 6(c)), suggesting that PPAR $\alpha$ suppressed cell autophagy in response to $\mathrm{H}_{2} \mathrm{O}_{2}$.

\section{Discussions}

Naoxintong (NXT) is an empirical formula based on the principle of traditional Chinese medicine, which has been approved by China Food and Drug Administration (CFDA) and is widely used for treatment of patients with cerebrovascular and cardiovascular diseases in China. Increasing evidences show that NXT alleviates atherosclerosis involved in reducing expression of iNOS and NO level in the vessel wall [2]. In the mice model of atherosclerosis, NXT suppresses atherosclerosis through lipid-lowering and inhibition of dendritic cell maturation [1]. Clinical observations show that NXT can increase the antiplatelet effect and decrease subsequent major adverse cardiovascular events (MACE) in patients with cytochrome $\mathrm{P} 4502 \mathrm{Cl}^{*} 2$ polymorphism undergoing percutaneous coronary intervention (PCI) [3]. In addition to that, NXT reduces the development of diabetic retinopathy involved in inhibition of the expression of CAS3, MMP-2/9, and TNF- $\alpha$ [4]. Moreover, NXT increases the effect on the catalytic activities of drug-metabolising CYP2C19 enzyme [19]. Although ethanol extraction of NXT 


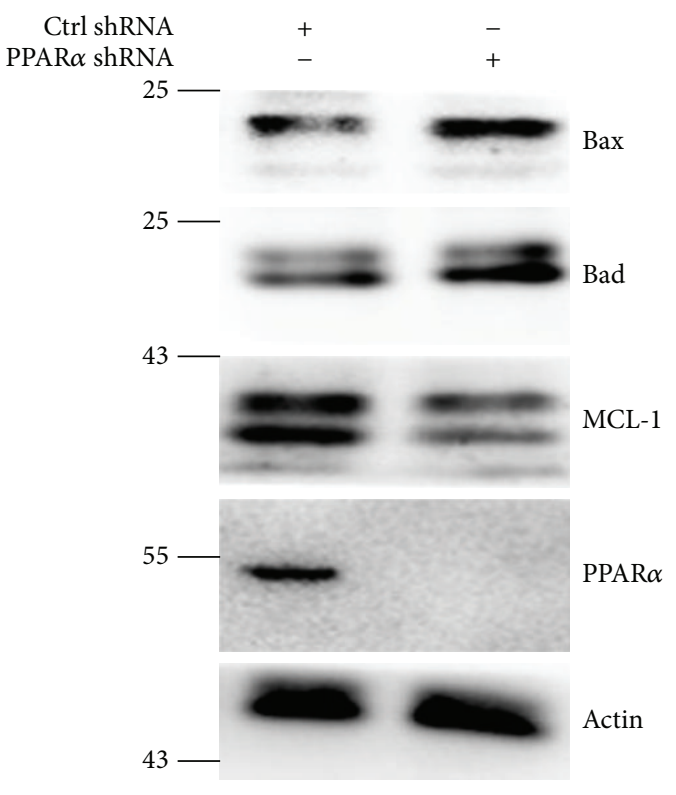

(a)

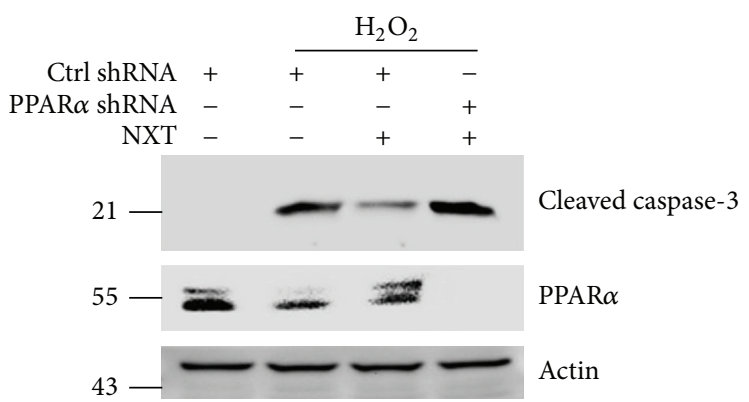

(b)

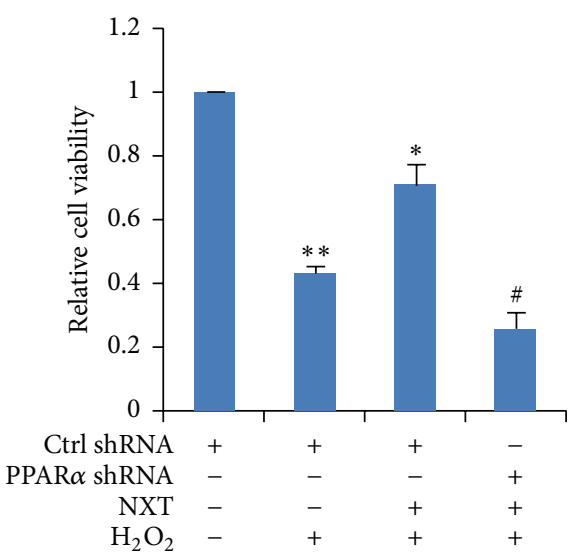

(c)

FIgURE 5: Silenced PPAR $\alpha$ decreases NXT protective effect on H9c2 cells. (a) H9c2 cells were transfected with control shRNA or PPAR $\alpha$ shRNA for $24 \mathrm{~h}$. Cell lysates were subjected to Western blot. Data are triplicates from three independent experiments. (b) H9c2 cells were transfected with control shRNA or PPAR $\alpha$ shRNA for $24 \mathrm{~h}$. Cells were pretreated with or without $0.5 \mu \mathrm{g} / \mathrm{mL} \mathrm{NXT}$ for $12 \mathrm{~h}$, and then cells were treated with $200 \mu \mathrm{M} \mathrm{H}_{2} \mathrm{O}_{2}$ for $6 \mathrm{~h}$. Cell lysates were subjected to Western blot. Data are triplicates from three independent experiments. (c) $\mathrm{H} 9 \mathrm{c} 2$ cells were transfected with control shRNA or PPAR $\alpha$ shRNA for $24 \mathrm{~h}$. Cells were pretreated with or without $0.5 \mu \mathrm{g} / \mathrm{mL}$ NXT for $12 \mathrm{~h}$, and then cells were treated with $200 \mu \mathrm{M} \mathrm{H}_{2} \mathrm{O}_{2}$ for $6 \mathrm{~h}$. Cell viability was assayed by MTT. Results are expressed as means \pm SEM $(n=5)$. ${ }^{* *} P<0.05$ versus control (no treatment); ${ }^{*} P<0.05$ versus only $\mathrm{H}_{2} \mathrm{O}_{2}$ treatment. ${ }^{*} P<0.05$ versus only $\mathrm{H}_{2} \mathrm{O}_{2}$ treatment.

reduces cardiomyocyte cell damage [5], the water soluble components of NXT on $\mathrm{H}_{2} \mathrm{O}_{2}$-induced cardiomyocyte cell apoptosis are still unclear. Here we found that the NXT water extract has significantly protective effect on $\mathrm{H} 9 \mathrm{c} 2$ cells in response to $\mathrm{H}_{2} \mathrm{O}_{2}$ treatment. To detect the possible component of the NXT water extract, the UHPLC-Q-TOF analysis was performed. Interestingly, the main composition of NXT water extract is paeoniflorin $(80.4 \%)$, salvianolic acid $\mathrm{B}(10.1 \%)$, trihydroxybenzoic acid (4.6\%), chlorogenic acid (1.8\%), and ferulic acid (1.5\%) (Table 1). These findings suggest that paeoniflorin may be the main or critical effective component for cardiovascular diseases, which needs to be further determined.
MCL-1 is the antiapoptotic proteins, but Bad and Bax are proapoptotic proteins, and MCL-1 inhibits caspase-3mediated cell apoptotic signaling pathway [20, 21]. It is well known that activated caspase- 3 results in cleavage of PARP1 leading to cell apoptosis [22]. Some natural compounds from traditional medicine increase $\mathrm{Bcl}-2$ family protein levels to inhibit cell apoptosis [23]. Our data show that NXT increased MCL-1 protein levels and decreased activation of caspase- 3 and PARP- 1 in $\mathrm{H}_{2} \mathrm{O}_{2}$-treated $\mathrm{H} 9 \mathrm{c} 2$ cells. These results show that NXT protected the cells against apoptosis by reducing caspase-3/PARP-1 signaling pathway. The increased antiapoptotic Bcl-2 family proteins (MCL-1) and decreased proapoptotic proteins (Bad and Bax) suggest that 


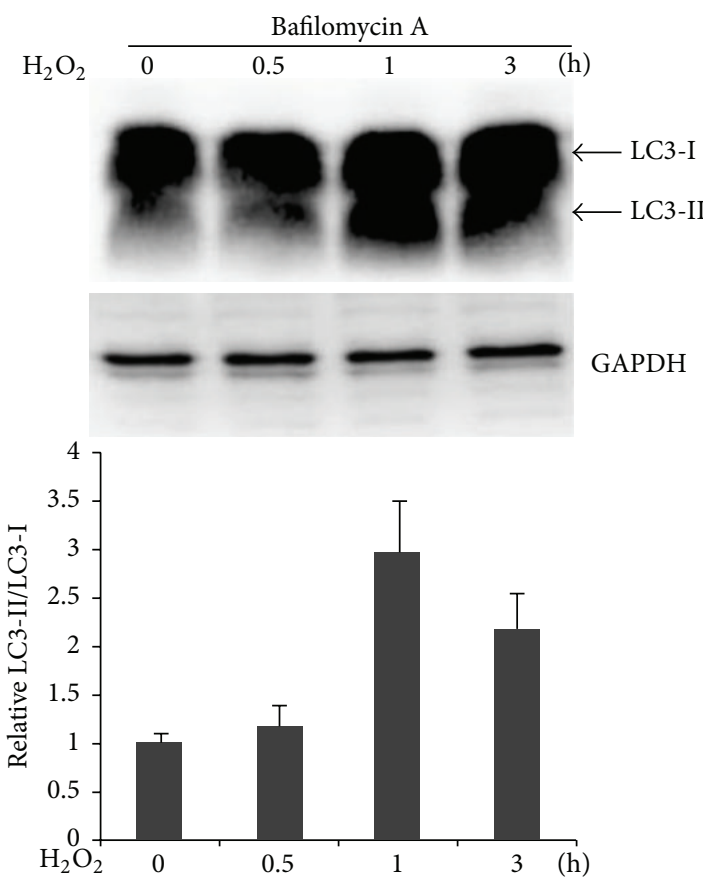

(a)
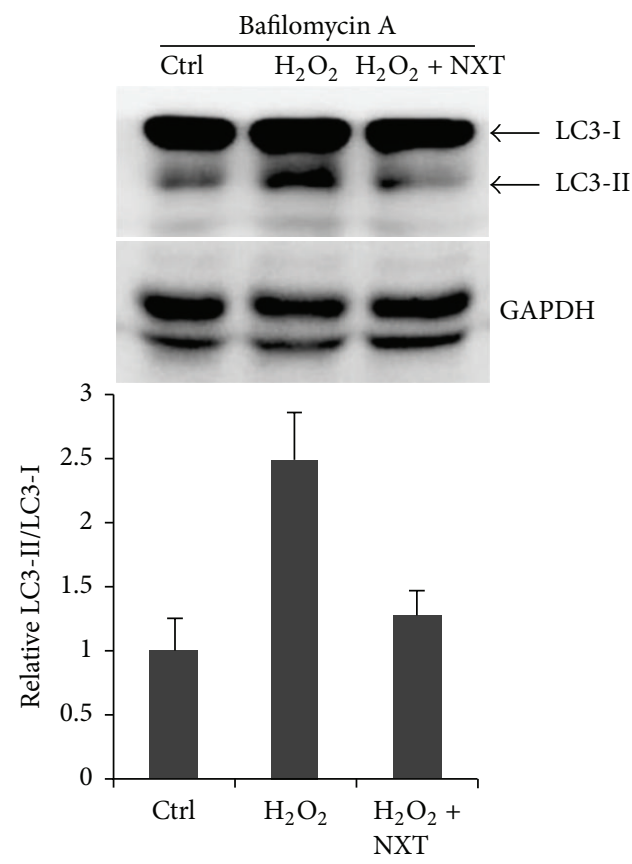

(b)

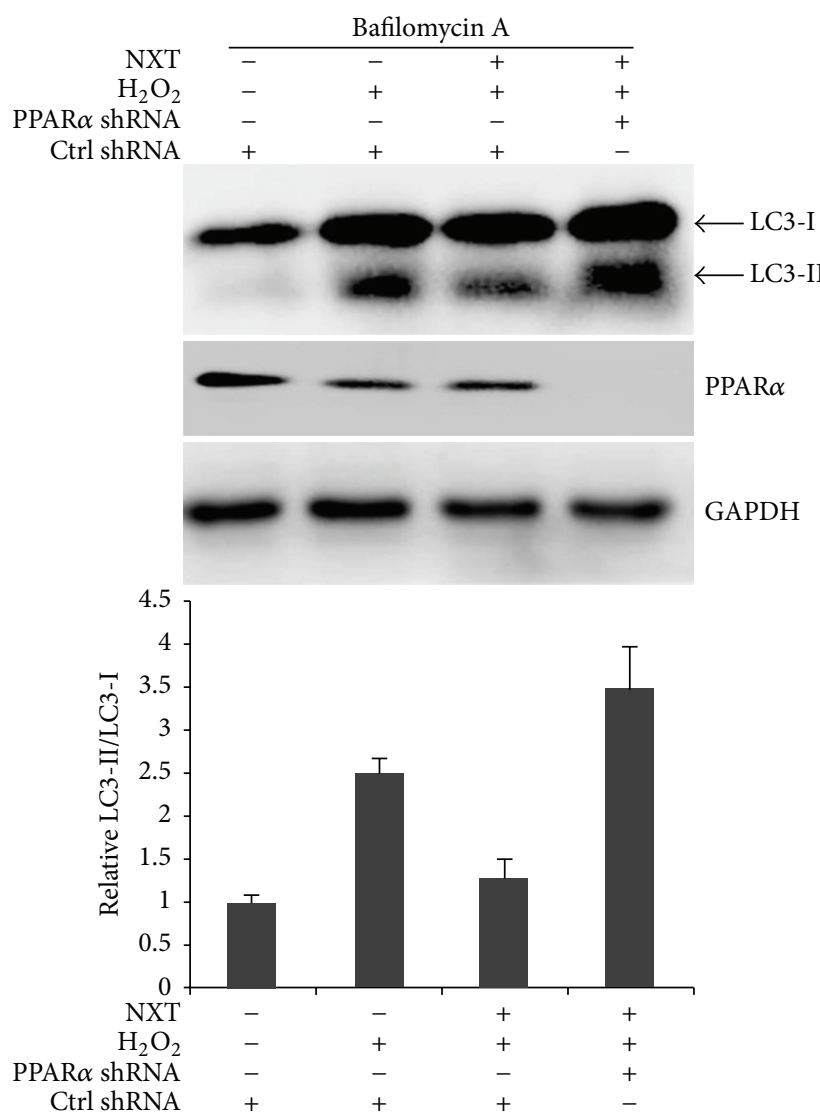

(c)

FIGURE 6: NXT/PPAR $\alpha$ signaling inhibits cell autophagy. (a) H9c2 cells were treated with $200 \mu \mathrm{M} \mathrm{H}_{2} \mathrm{O}_{2}$ as indicated time. Cell lysates were subjected to Western blot. (b) $\mathrm{H} 9 \mathrm{c} 2$ cells were treated with or without $0.5 \mu \mathrm{g} / \mathrm{mL}$ NXT for $12 \mathrm{~h}$. After that, cells were treated with $200 \mu \mathrm{M}$ $\mathrm{H}_{2} \mathrm{O}_{2}$ for 6 h. Cell lysates were subjected to Western blot. (c) H9c2 cells were transfected with control shRNA or PPAR $\alpha$ shRNA for 24 h. Cells were pretreated with or without $0.5 \mu \mathrm{g} / \mathrm{mL}$ NXT for $12 \mathrm{~h}$, and then cells were treated with $200 \mu \mathrm{M} \mathrm{H}_{2} \mathrm{O}_{2}$ for 6 h. Cell lysates were subjected to Western blot. Cells were treated with $50 \mu \mathrm{M}$ bafilomycin A for $1 \mathrm{~h}$ before cell lysis. Data are triplicates from three independent experiments. 
NXT extract reduced cell apoptosis in response to $\mathrm{H}_{2} \mathrm{O}_{2}$. FCM assay further demonstrated that NXT extract decreased $\mathrm{H} 9 \mathrm{c} 2$ cell apoptosis. MCL-1 is transmembrane protein in the mitochondria; however, Bax and Bak are two nuclearencoded proteins that are able to pierce the mitochondrial outer membrane to induce apoptosis [24]. Based on our findings, mitochondria may be one of the targets of NXT water extract.

As nuclear receptor, PPARs are the critical regulator of inflammation, adipocyte differentiation, and glucose homeostasis [3, 14-17]. Other reports show that $\operatorname{PPAR} \alpha$ protects against cardiomyocyte damage $[11,18]$. Here we found that NXT significantly increased PPAR $\alpha$ expression levels in response to $\mathrm{H}_{2} \mathrm{O}_{2}$. In contrast, silenced PPAR $\alpha$ terminated the inhibition of NXT on $\mathrm{H}_{2} \mathrm{O}_{2}$-induced $\mathrm{H} 9 \mathrm{c} 2$ cell damage involved in PPAR $\alpha$ mediated the MCL-1 antiapoptotic protein expression.

Autophagy delivers cytoplasmic materials or organelles into lysosomes for degradation, which is also a progress of nutrient recycling [25]. Especially in response to starvation stress, autophagy increases cell survival; however, long-term periods autophagy without new nutrients replenishment leads to digestion of all available substrates and death (autophagy-associated cell death) [12, 25]. Here we found that $\mathrm{H}_{2} \mathrm{O}_{2}$ significantly induced $\mathrm{H} 9 \mathrm{c} 2$ cell autophagy. In contrast, NXT reversed this event. More importantly, NXT reduced $\mathrm{H} 9 \mathrm{c} 2$ cell autophagy in a PPAR $\alpha$ dependent manner, suggesting that NXT/PPAR $\alpha$ signaling suppressed H9c2 cell autophagy.

\section{Conclusion}

NXT water extract inhibited $\mathrm{H} 9 \mathrm{c} 2$ cell apoptosis and autophagy by increasing PPAR $\alpha$ expression leading to increased $\mathrm{H} 9 \mathrm{c} 2$ cell viability.

\section{Competing Interests}

The authors declare that they have no competing interests.

\section{Authors' Contributions}

Huimin Xu and Jianhua Jin equally contributed to this work.

\section{Acknowledgments}

The authors acknowledge the financial support from the project supported by the National Natural Science Foundation of China (81173592), Program for New Century Excellent Talents in University of Ministry of Education of China (NCET-13-0935), Program of International S\&T Cooperation project of China (2015DFA30430), and the Program for Changjiang Scholars and Innovative Research Team in University, PCSIRT (IRT1276).

\section{References}

[1] J. Zhao, H. Zhu, S. Wang et al., "Naoxintong protects against atherosclerosis through lipid-lowering and inhibiting maturation of dendritic cells in LDL receptor knockout mice fed a high-fat diet," Current Pharmaceutical Design, vol. 19, no. 33, pp. 5891-5896, 2013.

[2] X.-N. Zhong, H.-H. Wang, Z.-Q. Lu et al., "Effects of naoxintong on atherosclerosis and inducible nitric oxide synthase expression in atherosclerotic rabbit," Chinese Medical Journal, vol. 126, no. 6, pp. 1166-1170, 2013.

[3] H. Xu, M. You, H. Shi, and Y. Hou, "Ubiquitin-mediated NF $\kappa$ B degradation pathway," Cellular and Molecular Immunology, vol. 12, no. 6, pp. 653-655, 2014.

[4] S. Grivennikov, E. Karin, J. Terzic et al., "IL-6 and Stat3 are required for survival of intestinal epithelial cells and development of colitis-associated cancer," Cancer Cell, vol. 15, no. 2, pp. 103-113, 2009.

[5] F. Zhang, B. Huang, Y. Zhao et al., "BNC protects $\mathrm{H} 9 \mathrm{c} 2$ cardiomyoblasts from $\mathrm{H}_{2} \mathrm{O}_{2}$-induced oxidative injury through ERK1/2 signaling pathway," Evidence-Based Complementary and Alternative Medicine, vol. 2013, Article ID 802784, 12 pages, 2013.

[6] E. De Marchi, F. Baldassari, A. Bononi, M. R. Wieckowski, and P. Pinton, "Oxidative stress in cardiovascular diseases and obesity: role of p66Shc and protein kinase C," Oxidative Medicine and Cellular Longevity, vol. 2013, Article ID 564961, 11 pages, 2013.

[7] J. L. Zweier and M. A. H. Talukder, "The role of oxidants and free radicals in reperfusion injury," Cardiovascular Research, vol. 70, no. 2, pp. 181-190, 2006.

[8] N. A. Turner, F. Xia, G. Azhar, X. Zhang, L. Liu, and J. Y. Wei, "Oxidative stress induces DNA fragmentation and caspase activation via the c-Jun $\mathrm{NH} 2$-terminal kinase pathway in H9c2 cardiac muscle cells," Journal of Molecular and Cellular Cardiology, vol. 30, no. 9, pp. 1789-1801, 1998.

[9] Y. Z. Hou, G. R. Zhao, J. Yang, Y. J. Yuan, G. G. Zhu, and R. Hiltunen, "Protective effect of Ligusticum chuanxiong and Angelica sinensis on endothelial cell damage induced by hydrogen peroxide," Life Sciences, vol. 75, no. 14, pp. 1775-1786, 2004.

[10] Y.-Z. Hou, G.-R. Zhao, Y.-J. Yuan, G.-G. Zhu, and R. Hiltunen, "Inhibition of rat vascular smooth muscle cell proliferation by extract of Ligusticum chuanxiong and Angelica sinensis," Journal of Ethnopharmacology, vol. 100, no. 1-2, pp. 140-144, 2005.

[11] G. Barreto-Torres, J. S. Hernandez, S. Jang et al., "The beneficial effects of AMP kinase activation against oxidative stress are associated with prevention of PPAR $\alpha$-cyclophilin D interaction in cardiomyocytes," American Journal of Physiology-Heart and Circulatory Physiology, vol. 308, no. 7, pp. H749-H758, 2015.

[12] R. S. Hotchkiss, A. Strasser, J. E. McDunn, and P. E. Swanson, "Cell death," The New England Journal of Medicine, vol. 361, no. 16, pp. 1570-1583, 2009.

[13] Y. Hou, F. Gao, Q. Wang et al., "Bcl2 impedes DNA mismatch repair by directly regulating the hMSH2-hMSH6 heterodimeric complex," The Journal of Biological Chemistry, vol. 282, no. 12, pp. 9279-9287, 2007.

[14] Y. Hou, J. Gao, H. Xu et al., "PPAR $\gamma$ E3 ubiquitin ligase regulates MUC1-C oncoprotein stability," Oncogene, vol. 33, pp. 56195625,2014

[15] Y. Hou, F. Moreau, and K. Chadee, "PPAR $\gamma$ is an E3 ligase that induces the degradation of $\mathrm{NF} \kappa \mathrm{B} / \mathrm{p} 65$," Nature Communications, vol. 3, article 1300, 2012.

[16] M. You, S. Yuan, J. Shi, and Y. Hou, "PPAR $\delta$ signaling regulates colorectal cancer," Current Pharmaceutical Design, vol. 21, no. 21, pp. 2956-2959, 2015. 
[17] Z. Zhang, Y. Xu, Q. Xu, and Y. Hou, "PPAR $\gamma$ against tumors by different signaling pathways," Onkologie, vol. 36, no. 10, pp. 598601, 2013.

[18] C.-H. Yeh, T.-P. Chen, C.-H. Lee, Y.-C. Wu, Y.-M. Lin, and P. J. Lin, "Cardiomyocytic apoptosis following global cardiac ischemia and reperfusion can be attenuated by peroxisome proliferator-activated receptor $\alpha$ but not $\gamma$ activators," Shock, vol. 26, no. 3, pp. 262-270, 2006.

[19] H. Chen, Y. Zhang, X. Wu, C. Li, and H. Wang, "In vitro assessment of cytochrome P450 2C19 potential of Naoxintong," Evidence-Based Complementary and Alternative Medicine, vol. 2012, Article ID 430262, 6 pages, 2012.

[20] A. N. Hata, J. A. Engelman, and A. C. Faber, "The BCL2 family: key mediators of the apoptotic response to targeted anticancer therapeutics," Cancer Discovery, vol. 5, no. 5, pp. 475-487, 2015.

[21] F. F. Zhou, Y. Yang, and D. Xing, "Bcl-2 and Bcl-xL play important roles in the crosstalk between autophagy and apoptosis," The FEBS Journal, vol. 278, no. 3, pp. 403-413, 2011.

[22] A. Gross, J. M. McDonnell, and S. J. Korsmeyer, "BCL-2 family members and the mitochondria in apoptosis," Genes \& Development, vol. 13, no. 15, pp. 1899-1911, 1999.

[23] P.-F. Wu, Z. Zhang, F. Wang, and J.-G. Chen, "Natural compounds from traditional medicinal herbs in the treatment of cerebral ischemia/reperfusion injury," Acta Pharmacologica Sinica, vol. 31, no. 12, pp. 1523-1531, 2010.

[24] J. Lindsay, M. D. Esposti, and A. P. Gilmore, "Bcl-2 proteins and mitochondria-specificity in membrane targeting for death," Biochimica et Biophysica Acta (BBA)-Molecular Cell Research, vol. 1813, no. 4, pp. 532-539, 2011.

[25] J. Kaur and J. Debnath, "Autophagy at the crossroads of catabolism and anabolism," Nature Reviews Molecular Cell Biology, vol. 16, no. 8, pp. 461-472, 2015. 


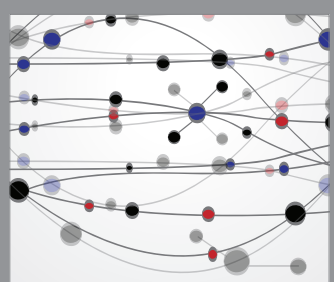

The Scientific World Journal
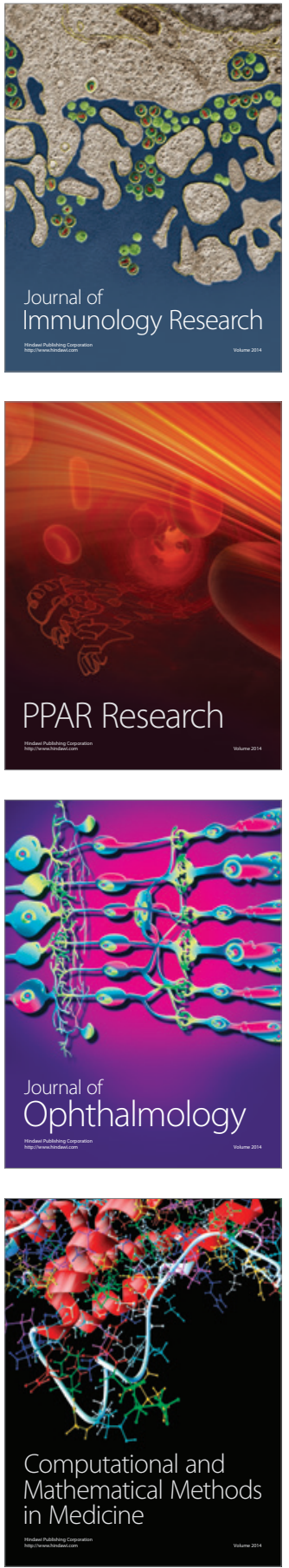

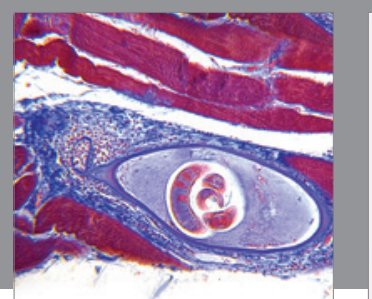

Gastroenterology Research and Practice

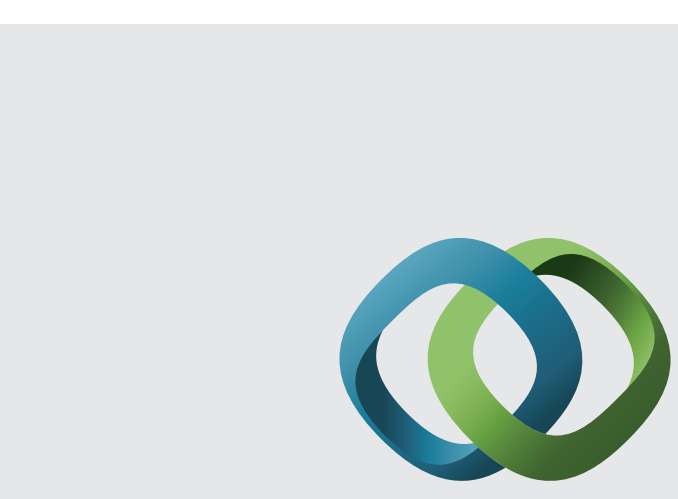

\section{Hindawi}

Submit your manuscripts at

http://www.hindawi.com
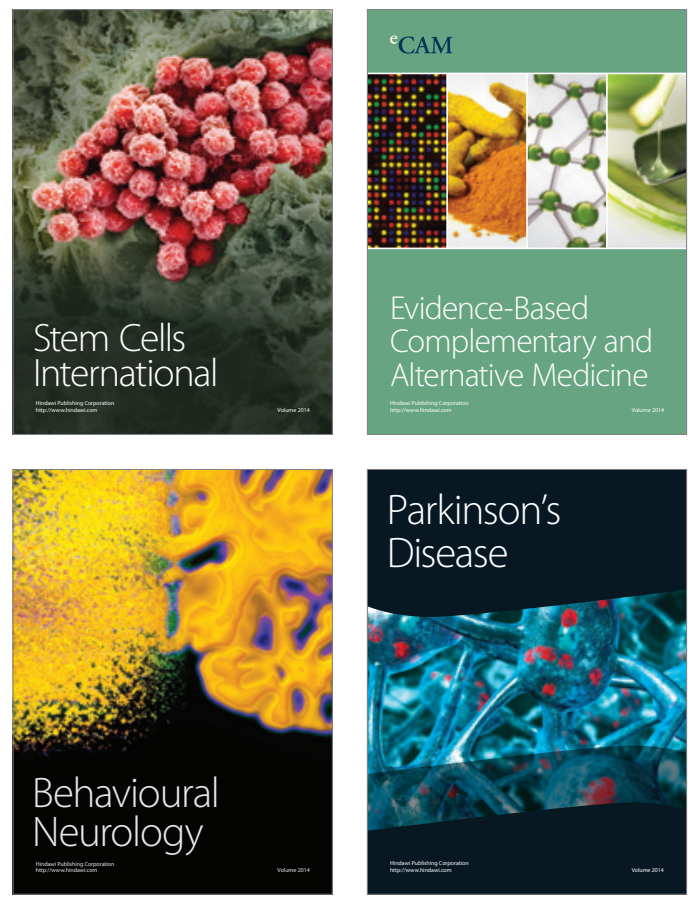
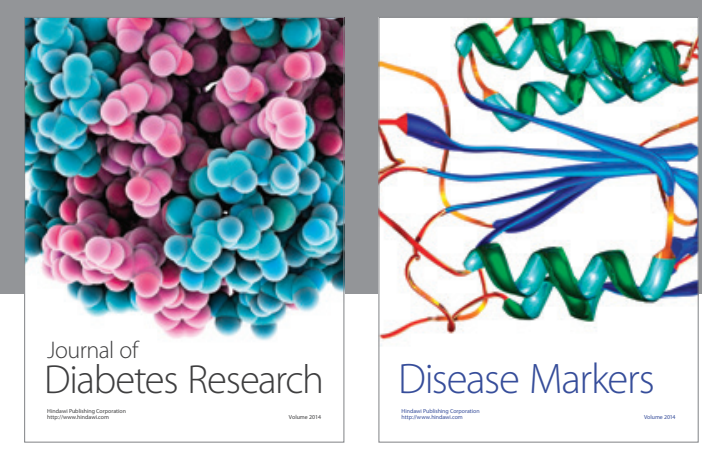

Disease Markers
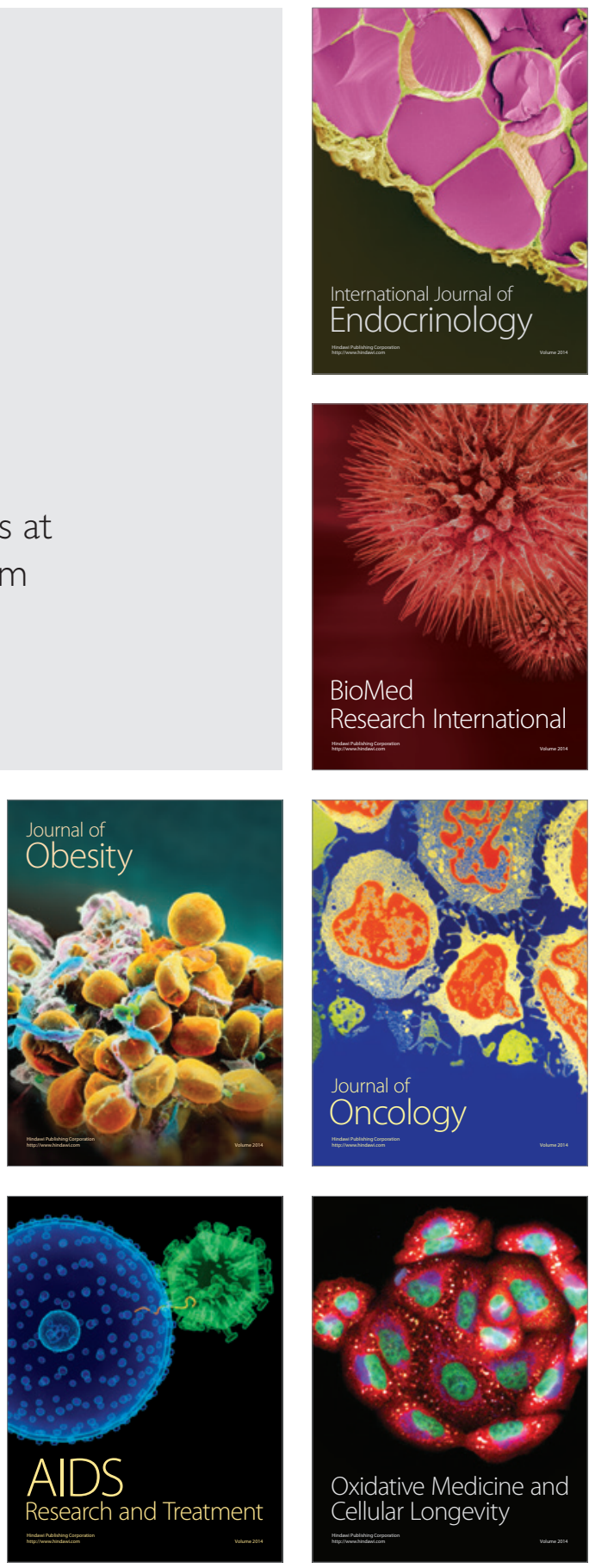